\title{
Mucosal gene expression profile of stricturing Crohn's disease: A preliminary study
}

\author{
CRISTIAN GEORGE TIERANU ${ }^{1,2^{*}}$, ANDREI OVIDIU OLTEANU ${ }^{2 *}$, \\ CARMEN MONICA PREDA ${ }^{1,3}$, NICOLAE BACALBASA ${ }^{1,4}$, ELENA MILANESI $^{5}$, \\ MARIA DOBRE $^{6}$, IOANA TIERANU ${ }^{1}$, TEODORA ECATERINA MANUC ${ }^{1,3}$, \\ ARTSIOM KLIMKO ${ }^{1}$, GABRIEL BECHEANU ${ }^{1,3,6}$ and ELENA MIRELA IONESCU ${ }^{1,2}$ \\ ${ }^{1}$ Department of Gastroenterology, 'Carol Davila' University of Medicine and Pharmacy, 050474 Bucharest; \\ ${ }^{2}$ Department of Gastroenterology, 'Elias' Emergency University Hospital, 011461 Bucharest; \\ Departments of ${ }^{3}$ Gastroenterology and ${ }^{4}$ Surgery, 'Fundeni' Clinical Institute, 022328 Bucharest; \\ Departments of ${ }^{5}$ Radiobiology and ${ }^{6}$ Pathology, 'Victor Babeş' National Institute of Pathology, 050096 Bucharest, Romania
}

Received September 21, 2021; Accepted October 21, 2021

DOI: $10.3892 /$ etm.2021.11072

\begin{abstract}
Intestinal strictures are an important complication of Crohn's disease (CD), with $\sim 40 \%$ of patients developing symptomatic obstruction within 10 years of diagnosis. However, there is a paucity of research examining the mechanisms driving the development of fibrotic strictures in CD. The present study aimed to identify the mucosal markers associated with stricturing complications by examining the differences in the gene expression profiles of two patient cohorts: Patients diagnosed with inflammatory CD $(n=12)$ and patients with stricturing $C D(n=9)$. For each patient, a paired sample of inflamed and uninflamed mucosa was isolated and assessed by quantitative PCR using a large panel of genes associated with inflammatory bowel disease. The presents study revealed a significantly increased level of four genes in the mucosa of patients with strictures compared with the inflammatory pattern of the disease: Formyl-peptide receptor 1 $[\mathrm{P}=0.019$; fold change $(\mathrm{FC})=11.6], \mathrm{C}-\mathrm{C}$ chemokine receptor type $1(\mathrm{P}=0.035 ; \mathrm{FC}=5.44), \mathrm{IFN}-\gamma$-inducible protein 10 $(\mathrm{P}=0.037 ; \mathrm{FC}=3.8)$ and $\mathrm{C}-\mathrm{C}$ chemokine ligand $25(\mathrm{P}=0.048$; $\mathrm{FC}=3.56)$. The augmented expression of these four genes in the CD stricturing phenotype, if confirmed in larger cohorts of patients, could help elucidate the mechanisms leading to disease-associated complications.
\end{abstract}

Correspondence to: Dr Maria Dobre, Department of Pathology, 'Victor Babeş' National Institute of Pathology, Splaiul Independenței 99-101, 050096 Bucharest, Romania

E-mail: maria_dobre70@yahoo.com

"Contributed equally

Key words: strictures, Crohn's disease, genes, formyl-peptide receptor 1 , IFN- $\gamma$-inducible protein $10, \mathrm{C}-\mathrm{C}$ chemokine ligand 25, C-C chemokine receptor type 1

\section{Introduction}

Crohn's disease (CD) is a chronic inflammatory disease of the gastrointestinal tract, with an evolution marked by alternating episodes of exacerbation and remission (1). The initial phase of $\mathrm{CD}$ is characterized by chronic digestive symptoms, such as diarrhea and weight loss, while longstanding CD is often complicated by the formation of strictures or fistulas (1). According to the Montreal classification, phenotypically, CD can be classified into three categories: B1-inflammatory (non-stricturing, non-penetrating), B2-stricturing and B3-penetrating (2).

Previous research has suggested that these phenotypic differences in $\mathrm{CD}$ are not due to intrinsic differences in the disease itself but rather due to the different stages of intestinal injury, manifesting a more or less protracted disease evolution (3-5). Clinically, the behavioral classification of CD is difficult and may not truly reflect the natural history of the disease, as the incidence of stricture formation may differ substantially, not only among different patients but also in the same individual (3).

The frequency of disease-associated fibrostenotic complications increases with time in the evolution of CD $(4,5)$. Indeed, intestinal strictures represent a common complication of $\mathrm{CD}$, with as many as $40 \%$ of patients with ileal CD developing clinical symptoms of obstruction (6,7). Intestinal obstruction secondary to stricture formation is a frequent indication for surgical management. Progressive intestinal resection further predisposes to postoperative morbidity, as these patients are more likely to develop short bowel syndrome (8).

Although immunosuppressive and biological treatments are expected to lower the CD-related incidence of complications in patients with high-risk $\mathrm{CD}$, the rate of complications does not significantly decrease despite the early initiation of immunosuppressive therapy (9).

To the best of our knowledge, the pathophysiological mechanisms underpinning the stricturing process have not been clarified. However, some clinical, environmental and endoscopic parameters have been postulated as risk factors. 
An age at onset below 40 years, perianal disease at diagnosis and the need for steroids during the first flare, together with a history of smoking, have a positive predictive clinical value for disabling CD (6). In particular, smoking is a risk factor for a faster rate of progression from diagnosis to the first stricture (10). The endoscopic parameter associated with a higher risk of surgical intervention is the presence of deep mucosal ulcerations (11). Furthermore, the location of inflammation in the small bowel rather than the colon has also been indicated to be predictive of stricturing disease (12).

Some genetic variants have been associated with a higher risk of progression from an inflammatory, structuring or penetrating phenotype: The rs4263839 variant in the TNF superfamily member 15 gene and rs2066847 in nucleotide binding oligomerization domain containing 2 (NOD2) have been associated with progression to the B2 or B3 phenotype during 10 years of follow-up (13). The effects of NOD2 and its genetic variants have been extensively studied in $\mathrm{CD}$, with the results highlighting their importance in disease progression (14,15). Rs2066844, rs2066847 and rs2066847 have been associated with stricturing and penetrating phenotypes, whereas rs2066847 has been most strongly associated with a severe CD course (14-17). However, a large genetic association study that included $>19,000$ patients with CD from 16 countries in Europe, North America and Australasia did not indicate an association with NOD2 and stricturing disease after accounting for disease location (18).

The inability to determine which patients are more prone to develop strictures and which could have a rapidly progressive disease remains an important knowledge gap. The present study aimed to identify the gene expression profiles of tissue samples from stricturing and inflammatory CD to improve the understanding of the different molecular events implicated in the two phenotypes.

For this purpose, the present study evaluated the gene expression profile of a panel of genes previously associated with inflammatory bowel disease (IBD) in paired mucosa samples of 12 patients with inflammatory CD and 9 patients with stricturing $\mathrm{CD}$.

\section{Materials and methods}

Patients. A total of 21 patients with CD (12 patients with inflammatory CD and 9 patients with stricturing CD) were enrolled at the Department of Gastroenterology and Hepatology of Elias Emergency University Hospital (Bucharest, Romania) and at Fundeni Clinical Institute (Bucharest,Romania) between May 2016 and September 2018. The diagnosis was made using the available guidelines from the European Crohn's and Colitis Organization (19). For each patient with $\mathrm{CD}$, paired colonic inflamed mucosa (IM) and non-inflamed mucosa (NIM) samples were obtained during colonoscopy, based on the endoscopic mucosal appearance of the same colonic segment. Recorded demographical data of the patients consisted of age, sex, disease location based on Montreal classification (2), disease evolution in months and class of drugs used as treatment at biopsy sampling. The inclusion criteria were: Diagnosis of $C D$, age $>18$ years and active lesions seen at colonoscopy. The exclusion criteria were: Lack of inflammatory lesions at colonoscopy and penetrating disease pattern. Samples for gene expression analysis were collected in RNAlater and were then processed at the laboratory for dry storage at $-80^{\circ} \mathrm{C}$. Endoscopically, IM was characterized by the presence of erythema, aphthous lesions, cobblestoning or deep ulcers. Stenosis was defined as the endoscopic appearance of the narrowing of the luminal caliber (Fig. 1) and was confirmed by computed tomography. Histological evaluation of the biopsies from the two groups was performed (Fig. 2). The tissue was fixed in formalin (10\%) for $24 \mathrm{~h}$ at room temperature using an Excelsior AS Tissue Processor (Thermo Scientific, Inc.) and embedded in paraffin at $60^{\circ} \mathrm{C}$ using the Modular Tissue Embedding center Myr EC350 (Especialidades Médicas Myr, S.L.). Sections with a thickness of $4 \mu \mathrm{m}$ were stained with Hematoxylin 7211 (Thermo Fisher Scientific, Inc.) and Eosin-Y (Thermo Fisher Scientific, Inc.) according to the manufacturer's protocol (staining at room temperature for 4 and $2.5 \mathrm{~min}$, respectively), using the automatic stainer Gemini AS slide stainer (Thermo Scientific, Inc.) and examined by a pathologist using a light microscope DM750 (Leica Microsystems $\mathrm{GmbH})$.

Ethical considerations. All patients included in the present study were of Romanian origin. The present study was presented to and evaluated and approved by the Elias Emergency University Hospital Ethics Committee (registration number 6598; May 11, 2015; Bucharest, Romania) and by the Fundeni Clinical Institute Ethics Committee (registration number 8007; February 23, 2018; Bucharest, Romania). All patients included in the present study signed a written informed consent form prior to biopsy sampling. The study protocol conformed to the ethical guidelines of the 1975 Declaration of Helsinki and its later amendments.

Total RNA isolation and quantitative PCR. Fresh-frozen tissues were preserved in RNAlater (Thermo Fisher Scientific, Inc.). Total RNA isolation was performed using the RNeasy Mini Kit (Qiagen $\mathrm{GmbH}$ ) according to the manufacturer's protocols. RNA quality and quantity were assessed using a NanoDrop 2000 instrument (Thermo Fisher Scientific, Inc.). RNA (600 ng) was reverse transcribed to cDNA using the RT2 First Strand Kit (Qiagen $\mathrm{GmbH}$ ) according to the manufacturer's protocols. The expression of 84 key genes (Table SI) was evaluated using the Human CD RT ${ }^{2}$ Profiler PCR Array (PAHS-169Z; Qiagen $\mathrm{GmbH}$ ), as previously reported (20), using SYBR Green chemistry (RT2 SYBR Green ROX qPCR Mastermix; Qiagen $\mathrm{GmbH}$ ) according to the manufacturer's protocols using the ABI-7500 fast instrument (Applied Biosystems; Thermo Fisher Scientific, Inc.). In the present study, the $2^{-\Delta \Delta \mathrm{Cq}}$ method was used (21). Each $\Delta \mathrm{Ct}$ value indicates the $\mathrm{Ct}$ value of the target gene relative to the geometric mean of the two housekeeping genes (GAPDH and HPRT1). The two housekeeping genes were selected as reported by Milanesi et al (22). The $\Delta \Delta \mathrm{Ct}$ value represents the $\Delta \mathrm{Ct}$ value of IM compared with NIM. The $2^{-\Delta \Delta \mathrm{Ct}}$ values were calculated for the stricturing and inflammatory CD samples: $\Delta \Delta \mathrm{Ct}=(C t \text {, target gene }-C t, H K s)_{\mathrm{IM}^{-}}(C t$, target gene $-C t$, $H K s)_{N I M}$

The fold change (FC) between the two groups (B2 vs. B1) was further identified as follows: $\mathrm{FC}=2^{-\Delta \Delta \mathrm{Ct}}(B 2) / 2^{-\Delta \Delta \mathrm{Ct}}(B 1)$. 


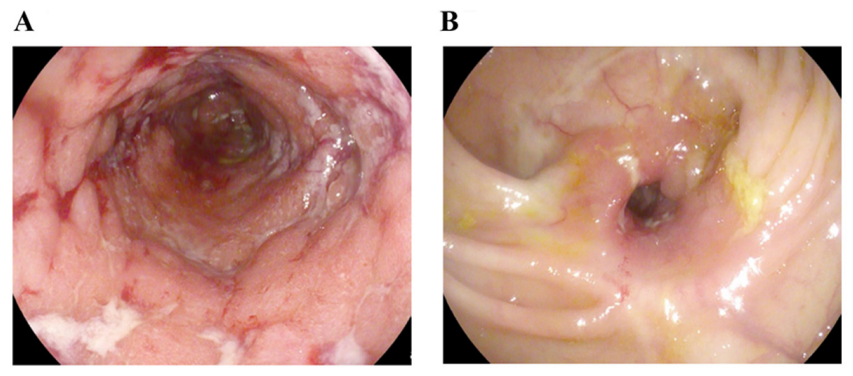

Figure 1. Endoscopic patterns of Crohn's disease. (A) Crohn's disease inflammatory pattern. Segment of a descending colon with a 'cobble-stone' appearance being entirely dehaustrated and presenting with hyperemia, edema, multiple profound erosions and spontaneous bleeding. (B) Crohn's disease stricturing pattern. Colonic stenosis, surrounding mucosa with a quasinormal pattern, and scarring. The visible part of the stricture presents with hyperemia, edema and deep ulceration.
A

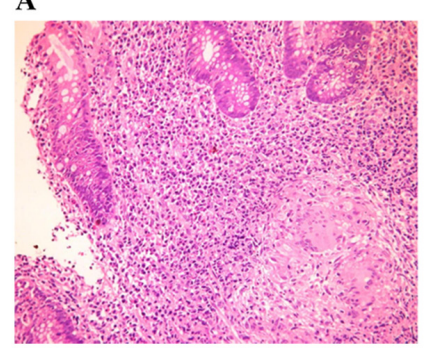

B

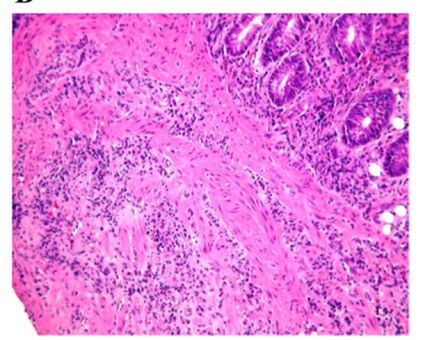

Figure 2. Histologic features of Crohn's disease. (A) Crohn's disease with severe transmucosal granulomatous inflammation, epithelioid granuloma in the submucosa and mucosal erosion. H\&E staining. Magnification, x200. (B) Stricturing colonic Crohn's disease with widening of the submucosa due to fibrosis and irregular thickening of the muscularis mucosae (muscularization of the submucosa). The colonic crypts are shorter, with basal plasmacytosis and inflammatory infiltrates extending into the submucosa. H\&E staining. Magnification, x100.

Statistical analysis. Statistical analysis was performed using the Statistical Package for the Social Sciences software (SPSS version 17.0; SPSS, Inc.). The categorical variable sex was tested using the means of the $\chi^{2}$ test, and the continuous variable age (mean age in years $\pm \mathrm{SD}$ ) was evaluated using an unpaired t-test. The non-parametric Mann-Whitney U test was used to assess the difference in gene expression levels between stricturing and inflammatory $\mathrm{CD}$. The analysis of gene expression data has been performed comparing the mean $\pm \mathrm{SD}$ of the $2^{-\Delta \Delta \mathrm{Cq}}$ values. Since the gene expression array is experimentally validated and includes many internal controls (see Table SI), no experimental replicates have been evaluated. Comparisons were considered significant with $\mathrm{P}<0.05$ and a $\mathrm{FC}>|3|$. The graphs were generated using GraphPad Prism 8 (GraphPad Software, Inc.).

\section{Results}

In the two groups of patients, no statistically significant difference was found in age $(\mathrm{P}=0.238)$ or $\operatorname{sex}\left(\chi^{2}=1.311 ; \mathrm{P}=0.252\right)$. Notably, more patients in the stricturing CD group were treated with biologic agents and the patients in the structuring CD group had a longer disease evolution from diagnosis; however, this was not statistically significant. The characteristics of the patients are presented in Table I.
Differential gene expression analysis between patients with stricturing and inflammatory $\mathrm{CD}$ revealed that, in the mucosa from patients with a stricturing phenotype (B2), 27 genes were upregulated and six genes were downregulated with an $\mathrm{FC}>|3|$ compared with the inflammatory phenotype (B1; Table II), and many of these were not statistically significant $(P>0.05)$. Four transcripts reached statistical significance $(\mathrm{P}<0.05)$ : $\mathrm{C}-\mathrm{C}$ chemokine receptor type $1(\mathrm{CCR} 1 ; \mathrm{P}=0.035 ; \mathrm{FC}=5.44)$, IFN- $\gamma$-inducible protein 10 (CXCL10; $\mathrm{P}=0.037 ; \mathrm{FC}=3.81$ ), $\mathrm{C}-\mathrm{C}$ chemokine ligand 25 (CCL25; $\mathrm{P}=0.048 ; \mathrm{FC}=3.56$ ) and formyl-peptide receptor 1 (FPR1; P=0.019; FC=11.61; Fig. 3).

\section{Discussion}

The present study aimed to identify the differences in gene expression profiles between inflammatory and stricturing $C D$ phenotypes. For this purpose, the present study analyzed paired mucosal samples from 9 patients with $\mathrm{B} 2 \mathrm{CD}$ and 12 patients with B1/B1p CD. Four transcripts, namely CCR1, CXCL10, CCL25 and FPR1, with significantly higher expression levels in stricturing than in inflammatory $\mathrm{CD}$ mucosa samples were identified.

The main limitation of the present study was the low number of patients with the stricturing phenotype. Furthermore, disease duration may also contribute to a change in mucosal inflammatory pathways, affecting gene expression profiles. Regarding the possible effect of biological treatment (more prominent in the stricturing phenotype group) on the gene expression levels, according to our previous results (23), the anti-TNF medications did not affect the levels of the differentially expressed genes identified in the present study. Nonetheless, these findings may be important for further research in the field of IBD, and each transcript will be addressed further.

CXCL10, CCL25 and CCR1 belong to the chemokine signaling pathway and serve as chemokines and chemokine receptors. Chemokines are key actors in directing the balance between physiological and pathophysiological inflammation in the gastrointestinal mucosa (24). In IBD, chemokines attract immune cells to inflamed and epithelial-damaged sites, and a majority of chemokines have been reported to be elevated in the mucosa of IBD (24).

The CCR1 gene encodes CCR1, which belongs to the $\mathrm{G}$ protein-coupled receptors. These receptors interact with $\mathrm{C}-\mathrm{C}$ motif chemokine ligand 3 (also referred to as macrophage inflammatory protein-1 $\alpha$ ), C-C motif chemokine ligand 5 or regulated on activation normal $\mathrm{T}$ expressed and secreted protein, $\mathrm{C}-\mathrm{C}$ motif chemokine ligand 7 or monocyte chemoattractant protein-3, and $\mathrm{C}-\mathrm{C}$ motif chemokine ligand 23 or myeloid progenitor inhibitory factor-1 (25). The first association between CCR1 and chronic bowel inflammation was revealed in animal models and was described by Ajuebor et al (24) in 2001. This study demonstrated increased mRNA levels in colonic tissue during the chronic phase of colitis ( $>7$ days after induced colitis) (24).

Recently, a Slovakian study revealed an increase in CCR1 mRNA expression in IM samples from patients with ulcerative colitis (UC) and CD compared with non-inflamed mucosal samples (26). Our previous results suggested that CCR1 may be a marker of molecular activity in CD (27). In the present study, increased CCR1 gene expression was observed in stricturing 
Table I. Clinical and demographic features of the patients enrolled in the present study.

\begin{tabular}{|c|c|c|c|}
\hline Parameters & $\begin{array}{l}\text { Patients with stricturing } \\
\text { CD }(B 2 ; n=9)\end{array}$ & $\begin{array}{l}\text { Patients with inflammatory } \\
\qquad \mathrm{CD}(\mathrm{B} 1 ; \mathrm{n}=12)\end{array}$ & P-value \\
\hline Age, years $($ mean $\pm S D)$ & $50.2 \pm 20.2$ & $40.4 \pm 12.4$ & $\mathrm{P}=0.238$ \\
\hline $\begin{array}{l}\text { Age at onset, years } \\
(\text { mean } \pm S D)\end{array}$ & $50.6 \pm 21.0$ & $35.6 \pm 12.2$ & $\mathrm{P}=0.053$ \\
\hline Male, $\%$ & 80 & 50 & $\begin{array}{l}\mathrm{P}=0.252 \\
\chi^{2}=1.311\end{array}$ \\
\hline $\begin{array}{l}\text { Perianal disease, \% } \\
\text { Extension } \\
\text { (Montreal score), \% }\end{array}$ & 0 & $16.7(n=2)$ & - \\
\hline $\mathrm{L} 1$ & $44.4(n=4)$ & $0(\mathrm{n}=0)$ & - \\
\hline $\mathrm{L} 2$ & $11.2(n=1)$ & $41.7(n=5)$ & - \\
\hline L3 & $44.4(n=4)$ & $58.3(n=7)$ & - \\
\hline $\begin{array}{l}\text { Months of evolution } \\
\text { Medications } \\
\text { (at biopsy acquisition), \% }\end{array}$ & $62.2 \pm 99.6$ & $36.4 \pm 45.1$ & $\mathrm{P}=0.434$ \\
\hline Biological & $33.4(n=3)$ & $8.3(n=1)$ & - \\
\hline 5-ASA & $22.2(n=2)$ & $33.3(n=4)$ & - \\
\hline 5-ASA+cortisone & $22.2(n=2)$ & $33.3(n=4)$ & - \\
\hline None & $22.2(n=2)$ & $25.0(n=3)$ & - \\
\hline
\end{tabular}

$\mathrm{CD}$, Crohn's disease; 5-ASA, 5-aminosalicylic acid.

A

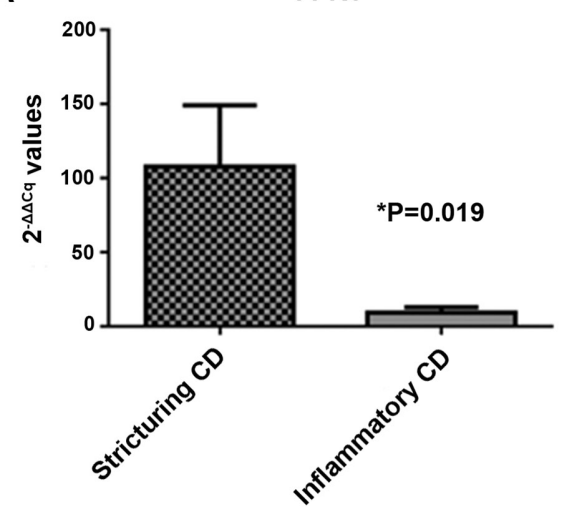

C

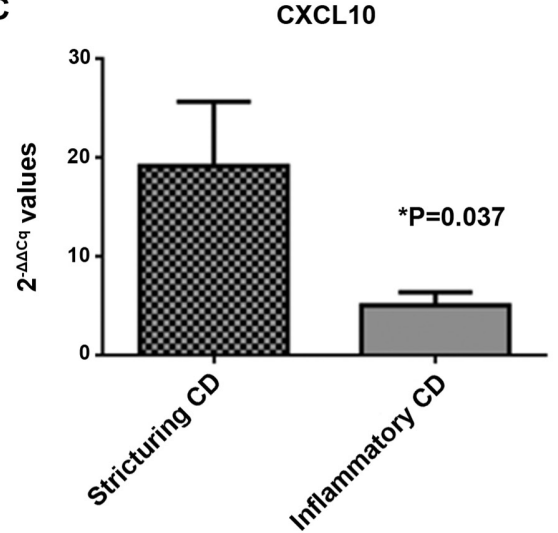

B

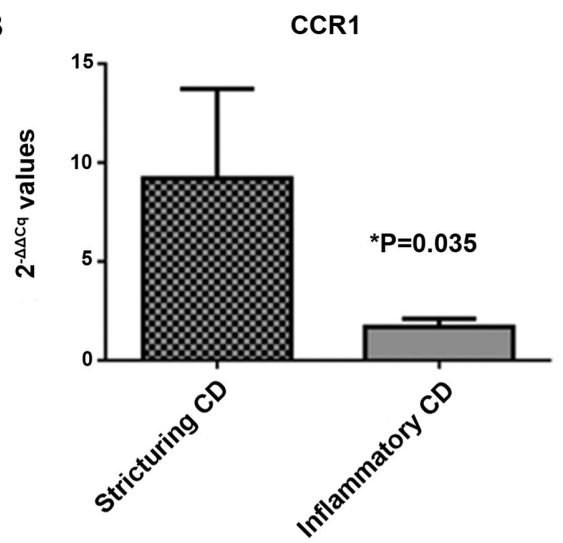

D

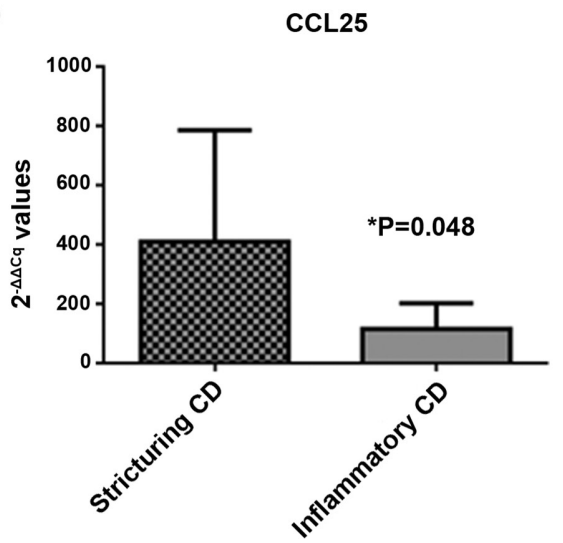

Figure 3. Genes differentially expressed between patients with structuring (B2) and inflammatory (B1) CD. (A) FPR1. (B) CCR1. (C) CXCL10. (D) CCL25. Gene expression levels are presented as $2^{-\Delta \Delta C q}$ values. "Statistical significance $(\mathrm{P}<0.05)$. CCL25, C-C chemokine ligand 25; CCR1, C-C chemokine receptor type 1; CXCL10, IFN- $\gamma$-inducible protein 10; FPR1, formyl-peptide receptor 1; CD, Crohn's disease. 
Table II. Differential expression of genes in patients with stricturing (B2) and inflammatory (B1) Crohn's disease.

\begin{tabular}{lrc}
\hline Gene & $\begin{array}{r}\text { Fold change } \\
\text { (B2 vs. B1) }\end{array}$ & P-value \\
\hline FPR1 & 11.61 & 0.019 \\
CCR1 & 5.44 & 0.035 \\
CXCL10 & 3.81 & 0.037 \\
CCL25 & 3.56 & 0.048 \\
MUC1 & -7.68 & 0.082 \\
VWF & 3.25 & 0.082 \\
IFNG & 3.61 & 0.104 \\
S100A9 & 5.84 & 0.104 \\
EGR3 & 7.71 & 0.130 \\
IL2RA & 4.98 & 0.130 \\
MMP1 & 116.34 & 0.195 \\
MMP3 & 35.51 & 0.195 \\
TNF & 3.39 & 0.195 \\
ALDOB & 21.26 & 0.234 \\
CXCR1 & 7.18 & 0.234 \\
CXCL8 & 17.47 & 0.234 \\
S100A8 & 9.67 & 0.234 \\
IL1RN & 4.67 & 0.279 \\
CHI3L1 & 4.35 & 0.328 \\
TDO2 & 13.83 & 0.328 \\
CXCL12 & 3.83 & 0.383 \\
SELL & 19.66 & 0.383 \\
CSTA & 3.19 & 0.442 \\
SELE & 13.67 & 0.442 \\
MMP7 & 6.59 & 0.506 \\
IL6 & 12.65 & 0.560 \\
REG1B & -4.80 & 0.574 \\
IL1B & 9.70 & 0.646 \\
PCK1 & -5.36 & 0.646 \\
CCL2 & 5.01 & 0.721 \\
DEFA5 & -5.80 & 0.721 \\
REG1A & -13.30 & 0.799 \\
SAA1 & -7.08 & 0.879 \\
\hline
\end{tabular}

The genes are presented based on the P-value (decreasing order of statistical significance).

CD compared with inflammatory $\mathrm{CD}$. This suggested that CCR1 may be implicated in disease progression and tissue destruction.

CXCL10 and CCL25 are two chemokines involved in T-cell recruitment, and thus, serve an important role in regulating the gastrointestinal immune response and enabling mucosal inflammation (28).

CXCL10 is secreted by immune cells, such as T-cells, B-cells, NK cells and myeloid cells (28). It targets the C-X-C motif chemokine receptor 3 (CXCR3) receptor (28). It can be detected in blood, normal colonic mucosa and tissues with active inflammation, including IBD (28). The activation of CXCR3 upregulates CXCL10, which is expressed by non-immune cells, such as epithelial cells and fibroblasts (29). Inflammation induced by interferon $\gamma$, tumor necrosis factor $\alpha$ and interleukin- $1 \beta$ can further increase CXCL10 expression (30). CCL25, which is the only C-C motif chemokine receptor 9 ligand, was considered to be exclusively expressed in the lamina propria by mononuclear cells of the small intestine and the thymus for years (31). However, recent data have extended these observations, revealing its expression in the colon and liver (32).

Studies examining the roles of CXCL10 and CXCR3 in IBD continue to find novel advancements. Plasmatic levels of CXCL10 are markedly increased in patients with IBD compared with non-IBD controls (33). In patients with CD, CXCL10 serum levels remain upregulated during flares and remission (34). Furthermore, higher expression levels of CXCL10 and CXCR3 have been observed in multiple studies comparing active IBD mucosa with mucosa from non-IBD controls $(34,35)$.

CCL25 gene expression is positively associated with both the Mayo endoscopic subscore and mucosal TNF $\alpha$ levels (36). The elevated serum levels of this chemokine have also been reported in patients with UC (28). To the best of our knowledge, the present study was the first to report higher gene expression levels of CXCL10 and CCL25 in stricturing CD, suggesting the presence of more prominent inflammatory stimuli in these patients compared with in patients with purely inflammatory $\mathrm{CD}$.

FPR1 was the most significantly upregulated gene in stricturing CD found in the present study. It encodes a G-coupled protein receptor and serves a crucial role in inflammation, as it is a prominent catalyst for neutrophil sensing and chemoattraction (37). FPR1 was the first member described in this family (38). Upon activation, it regulates multiple functions, such as chemotaxis, degranulation, reactive oxygen species synthesis and phagocytosis (39). The main ligands for FPR1 are formylated peptides of both mitochondrial and bacterial origin secreted by invading pathogens or released from apoptotic cells (40).

Data regarding FPR families in murine models has revealed their role in rapid neutrophil mobilization, in which neutrophil infiltration augmented wound-healing capacities in sterile skin lesions (41). In the intestinal lumen, in which the number of $\mathrm{N}$-formyl peptides is elevated due to the bacterial burden, the polymorphonuclear cell-mediated response is important (39). Increased intramucosal levels of these peptides, possibly as a consequence of epithelial barrier damage, can contribute to the activation of FPR 1 and the development of intestinal crypt abscesses in acute and chronic IBD (34). In the present study, increased FPR1 gene expression was noted in stricturing CD compared with the inflammatory phenotype. Consequently, this puts emphasis on data that implicate FPR1 in wound healing. To the best of our knowledge, the present study was the first to report a link between FPR1 and CD in humans.

In conclusion, the present study revealed four transcripts that were differentially expressed between inflammatory and stricturing CD. CCR1, CXCL10, CCL25 and FPR1 were all significantly upregulated in stricturing $\mathrm{CD}$. Despite the low number of patients analyzed, the present preliminary results are promising. Future studies on the transcriptional profiling of CD may offer vital insights into the mechanisms of stricture formation in $\mathrm{CD}$ and aid in predicting disease evolution and stricturing complications. 


\section{Acknowledgements}

Not applicable.

\section{Funding}

The present study was supported by Ministry of Education and Research in Romania (grant nos. 7PFE/16.10.2018 and PN 1N/2019_19.29.01.05).

\section{Availability of data and materials}

The datasets used and/or analyzed during the current study are available from the corresponding author on reasonable request.

\section{Authors' contributions}

CGT and AOO confirm the authenticity of all the raw data. CGT and AOO contributed to conception and design, data acquisition, drafting and revising of the manuscript. CMP, NB, EM and MD contributed to data acquisition, analysis and interpretation. TEM, GB and IT contributed to data acquisition and drafting of the manuscript. AK and EMI have been involved in conception and design of the study, drafting the manuscript and revising it critically for important intellectual content. All authors have read and approved the final manuscript.

\section{Ethics approval and consent to participate}

The present study was approved by the Elias Emergency University Hospital Ethics Committee (registration number 6598; May 11, 2015; Bucharest, Romania) and the Fundeni Clinical Institute Ethics Committee (registration number 8007; February 23, 2018; Bucharest, Romania). All patients included in the present study signed a written informed consent form on enrollment.

\section{Patient consent for publication}

Not applicable.

\section{Competing interests}

The authors declare that they have no competing interests.

\section{References}

1. Bettenworth D, Nowacki TM, Cordes F, Buerke B and Lenze F: Assessment of stricturing Crohn's disease: Current clinical practice and future avenues. World J Gastroenterol 22: 1008-1016, 2016.

2. Satsangi J, Silverberg MS, Vermeire S and Colombel JF: The Montreal classification of inflammatory bowel disease: Controversies, consensus, and implications. Gut 55: 749-753, 2006.

3. Freeman HJ: Natural history and long-term clinical course of Crohn's disease. World J Gastroenterol 20: 31-36, 2014.

4. Cosnes J, Gower-Rousseau C, Seksik P and Cortot A: Epidemiology and natural history of inflammatory bowel diseases. Gastroenterology 140: 1785-1794, 2011.

5. Cosnes J, Cattan S, Blain A, Beaugerie L, Carbonnel F, Parc R and Gendre JP: Long-term evolution of disease behavior of Crohn's disease. Inflamm Bowel Dis 8: 244-250, 2002.
6. Solberg IC, Vatn MH, Høie O, Stray N, Sauar J, Jahnsen J, Moum B, Lygren I and IBSEN Study Group: Clinical course in Crohn's disease: Results of a norwegian population-based ten-year follow-up study. Clin Gastroenterol Hepatol 5: 1430-1438, 2007.

7. Louis E, Collard A, Oger AF, Degroote E, Aboul Nasr El Yafi F and Belaiche J: Behaviour of Crohn's disease according to the Vienna classification: Changing pattern over the course of the disease. Gut 49: 777-782, 2001.

8. Frolkis AD, Lipton DS, Fiest KM, Negrón ME, Dykeman J, deBruyn J, Jette N, Frolkis T, Rezaie A, Seow CH, et al: Cumulative incidence of second intestinal resection in Crohn's disease: A systematic review and meta-analysis of population-based studies. Am J Gastroenterol 109: 1739-1748, 2014.

9. Cosnes J, Nion-Larmurier I, Beaugerie L, Afchain P, Tiret E and Gendre JP: Impact of the increasing use of immunosuppressants in Crohn's disease on the need for intestinal surgery. Gut 54: 237-241, 2005.

10. Louis E, Michel V, Hugot JP, Reenaers C, Fontaine F, Delforge M, El Yafi F, Colombel JF and Belaiche J: Early development of stricturing or penetrating pattern in Crohn's disease is influenced by disease location, number of flares, and smoking but not by NOD2/CARD15 genotype. Gut 52: 552-557, 2003.

11. Allez $M$ and Lémann $M$ : Role of endoscopy in predicting the disease course in inflammatory bowel disease. World J Gastroenterol 16: 2626-32, 2010.

12. Pernat Drobež C, Ferkolj I, Potočnik U and Repnik K: Crohn's disease candidate gene alleles predict time to progression from inflammatory B1 to stricturing B2, or penetrating B3 phenotype. Genet Test Mol Biomarkers 22: 143-151, 2018.

13. Adler J, Rangwalla SC, Dwamena BA and Higgins PD: The prognostic power of the NOD2 genotype for complicated Crohn's disease: A meta-analysis. Am J Gastroenterol 106: 699-712, 2011.

14. Tolentino YF, Elia PP, Fogaça HS, Carneiro AJ, Zaltman C, Moura-Neto R, Luiz RR, Carvalho Mda G and de Souza HS: Common NOD2/CARD15 and TLR4 polymorphisms are associated with Crohn's disease phenotypes in southeastern brazilians. Dig Dis Sci 61: 2636-2647, 2016.

15. Cleynen I, González JR, Figueroa C, Franke A, McGovern D, Bortlík M, Crusius BJ, Vecchi M, Artieda M, Szczypiorska M, et al: Genetic factors conferring an increased susceptibility to develop Crohn's disease also influence disease phenotype: Results from the IBDchip European project. Gut 62: 1556-1565, 2013

16. Schnitzler F, Friedrich M, Wolf C, Angelberger M, Diegelmann J, Olszak T, Beigel F, Tillack C, Stallhofer J, Göke B, et al: The NOD2 p.Leu1007fsX1008 mutation (rs2066847) is a stronger predictor of the clinical course of Crohn's disease than the FOXO3A intron variant rs12212067. PLoS One 9: e108503, 2014.

17. Cleynen I, Boucher G, Jostins L, Schumm LP, Zeissig S, Ahmad T, Andersen V, Andrews JM, Annese V, Brand S, et al: Inherited determinants of Crohn's disease and ulcerative colitis phenotypes: A genetic association study. Lancet 387: 156-167, 2016.

18. Magro F, Gionchetti P, Eliakim R, Ardizzone S, Armuzzi A, Barreiro-de Acosta M, Burisch J, Gecse KB, Hart AL, Hindryckx P, et al: Third European evidence-based consensus on diagnosis and management of ulcerative colitis. Part 1: Definitions, diagnosis, extra-intestinal manifestations, pregnancy, cancer surveillance, surgery, and ileo-anal pouch disorders. J Crohns Colitis 11: 649-670, 2017.

19. Tieranu CG, Dobre M, Mănuc TE, Milanesi E, Plesea IE, Popa C, Mănuc M, Ţieranu I, Preda CM, Diculescu MM, et al: Gene expression profile of endoscopically active and inactive ulcerative colitis: Preliminary data. Rom J Morphol Embryol 58: 1301-1307, 2017.

20. Dobre M, Milanesi E, Mănuc TE, Arsene DE, Ţieranu CG, Maj C, Becheanu G and Mănuc M: Differential intestinal mucosa transcriptomic biomarkers for Crohn's disease and ulcerative colitis. J Immunol Res 2018: 9208274, 2018.

21. Livak KJ and Schmittgen TD: Analysis of relative gene expression data using real-time quantitative PCR and the 2(-Delta Delta C(T)) method. Methods 25: 402-408, 2001.

22. Milanesi E, Dobre M, Manuc T, Becheanu G, Tieranu CG, Ionescu EM and Manuc M: Mucosal gene expression changes induced by anti-TNF treatment in inflammatory bowel disease patients. Drug Dev Res 80: 831-836, 2019.

23. Grimm MC and Doe WF: Chemokines in inflammatory bowel disease Mucosa: Expression of RANTES, Macrophage Inflammatory Protein (MIP)-1 $\alpha$, MIP-1 $\beta$, and $\gamma$-InterferonInducible Protein-10 by Macrophages, Lymphocytes, Endothelial Cells, and Granulomas. Inflamm Bowel Dis 2: 88-96, 1996. 
24. Ajuebor MN, Hogaboam CM, Kunkel SL, Proudfoot AE and Wallace JL: The chemokine RANTES is a crucial mediator of the progression from acute to chronic colitis in the rat. J Immunol 166: 552-558, 2001.

25. Kristensen NN, Olsen J, Gad M and Claesson MH: Genome-wide expression profiling during protection from colitis by regulatory T cells. Inflamm Bowel Dis 14: 75-87, 2008.

26. Mayer L, Sandborn WJ, Stepanov Y, Geboes K, Hardi R, Yellin M, Tao X, Xu LA, Salter-Cid L, Gujrathi S, et al: Anti-IP-10 antibody (BMS-936557) for ulcerative colitis: A phase II randomised study. Gut 63: 442-450, 2014.

27. Dobre M, Manuc T, Milanesi E, Pleşea IE, Tुieranu EN, Popa C Mănuc M, Preda CM, Tieranu I, Diculescu MM, et al: Mucosal CCR1 gene expression as a marker of molecular activity in Crohn's disease: Preliminary data. Rom J Morphol Embriol 58: 1263-1268, 2017.

28. Trivedi PJ, Bruns T, Ward S, Mai M, Schmidt C, Hirschfield GM, Weston CJ and Adams DH: Intestinal CCL25 expression is increased in colitis and correlates with inflammatory activity. J Autoimmun 68: 98-104, 2016.

29. Singh UP, Venkataraman C, Singh R and Lillard JW Jr: CXCR3 Axis: Role in inflammatory bowel disease and its therapeutic implication. Endocrine Metab Immune Disord Targets 7 : 111-123, 2007.

30. Singh UP, Singh NP, Murphy EA, Price RL, Fayad R, Nagarkatti $M$ and Nagarkatti PS: Chemokine and cytokine levels in inflammatory bowel disease patients. Cytokine 77: 44-49, 2016.

31. Svensson M and Agace WW: Role of CCL25/CCR9 in immune homeostasis and disease. Expert Rev Clin Immunol 2: 759-773, 2006.

32. Vasilyeva E, Abdulkhakov S, Cherepnev G, Martynova E, Mayanskaya I, Valeeva A, Abdulkhakov R, Safina D, Khaiboullina S and Rizvanov A: Serum cytokine profiles in children with Crohn's disease. Mediators Inflamm 2016: 7420127 2016.
33. Hosomi S, Oshitani N, Kamata N, Sogawa M, Okazaki H, Tanigawa $\mathrm{T}$, Yamagami $\mathrm{H}$, Watanabe $\mathrm{K}$, Tominaga $\mathrm{K}$, Watanabe T, et al: Increased numbers of immature plasma cells in peripheral blood specifically overexpress chemokine receptor CXCR 3 and CXCR4 in patients with ulcerative colitis. Clin Exp Immunol 163: 215-224, 2011.

34. Østvik AE, Granlund AV, Torp SH, Flatberg A, Beisvåg V, Waldum HL, Flo TH, Espevik T, Damås JK and Sandvik AK: Expression of Toll-like receptor-3 is enhanced in active inflammatory bowel disease and mediates the excessive release of lipocalin 2. Clin Exp Immunol 173: 502-511, 2013.

35. Uguccioni M, Gionchetti P, Robbiani DF, Rizzello F, Peruzzo S, Campieri $\mathrm{M}$ and Baggiolini $\mathrm{M}$ : Increased expression of IP-10, IL-8, MCP-1, and MCP-3 in Ulcerative Colitis. Am J Pathol 155: 331-336, 1999.

36. Kolaczkowska E and Kubes P: Neutrophil recruitment and function in health and inflammation. Nat Rev Immunol 13: 159-175, 2013.

37. Le Y, Ye RD, Gong W, Li J, Iribarren P and Wang JM: Identification of functional domains in the formyl peptide receptor-like 1 for agonist-induced cell chemotaxis. FEBS J 272: 769-778, 2005.

38. Boulay F, Tardif M, Brouchon L and Vignais P: Synthesis and use of a novel $\mathrm{N}$-formyl peptide derivative to isolate a human $\mathrm{N}$-formyl peptide receptor cDNA. Biochem Biophys Res Commun 168: 1103-1109, 1990.

39. Dorward DA, Lucas CD, Chapman GB, Haslett C, Dhaliwal K and Rossi AG: The role of formylated peptides and formyl peptide receptor 1 in governing neutrophil function during acute inflammation. Am J Pathol 185: 1172-1184, 2015.

40. Leoni G, Gripentrog J, Lord C, Riesselman M, Sumagin R, Parkos CA, Nusrat A and Jesaitis AJ: Human neutrophil formyl peptide receptor phosphorylation and the mucosal inflammatory response. J Leukoc Biol 97: 87-101, 2015.

41. VanCompernolle SE, Clark KL, Rummel KA and Todd SC: Expression and function of formyl peptide receptors on human fibroblast cells. J Immunol 171: 2050-2056, 2003. 